\title{
PLATES AND MAPS
}

\section{Plates}

1 A wine label from Podstrana, Croatia, featuring the sword in the stone. () The author.

2 St Martin's Church, Podstrana. ( $)$ The author.

3 The larger 'Artorius' inscription, St Martin’s Church, Podstrana. ( $)$ Drazen Marsic.

4 One of three pieces of the smaller 'Artorius' inscription, Archaeological Museum of Split. @ Nenad Cambj.

5 Drawing of a scene on Trajan's Column depicting Sarmatian warriors in flight from Roman cavalry. ( $)$ Maggie Kneen.

6 'Sarmatian' beads from Chesters Roman fort on Hadrian's Wall. Courtesy of the Trustees of the Clayton Collection and English Heritage.

7 A funerary relief carving of a probable Sarmatian cavalryman found at Chester. @ West Cheshire Museums.

8 A lead 'tamga' from Ribchester. ( $)$ Ribchester Roman Museum.

9 The 'Apollo' monument from Ribchester. (@) Ribchester Roman Museum.

10 Sarmatian burial mounds at Vaskút, Hungary. @ Visy Zsolt.

11 Mid-fifth-century Sarmatian pottery from excavations of the brick factory site at Tiszaföldvár, Hungary. @ Andrea Vaday.

12 Sarmatian beads of the mid-fifth century from excavations of the brick factory site at Tiszaföldvár, Hungary. ๑ Andrea Vaday.

13 Fourth- and fifth-century levels under excavation at Ribchester in 2016.

(c) Duncan Sayer. 
14 A stone footprint at the Dál Riatan stronghold of Dunadd, Argyll, Scotland. (C) The author.

15 The late medieval crozier of the archbishop of Siena. () Luca Larpi.

16 A mountain village in the Caucasus, illustrated in Douglas Freshfield, Travels in the Central Caucasus and Bashan (London, 1869).

17 The Mote of Mark, Dumfries and Galloway, Scotland. @ The author.

18 The Battersea Cauldron, c. 800-700 BCE. @ The Trustees of the British Museum.

19 The Antiochos dedication, Chester, England. @ West Cheshire Museums.

20 The 'astronomer' mosaic, Brading Villa, Isle of Wight, England. ๑ Oglander Roman Trust.

21 Part of the archivolt of the Porta della Pescheria in Modena Cathedral, Italy. (c) Elizabeth Lapina.

22 The Winchester Round Table, Winchester Castle, England. @ John Critchley/ Historic England Archive.

23 South Cadbury hillfort, Somerset, England. (c) Historic England Archive.

24 The farm of Camlan Uchaf in the small township of Camlan, Wales. @ The author.

25 Pen-y-Fan viewed from Cribyn, Brecon Beacons, Wales. @ Dave Dunford.

26 Arthur's Stone, a Bronze Age burial site at Llanrhidian Lower, Gower Peninsula, Wales. () The author.

27 'King Arthur's Hall' near St Breward, Cornwall, England. (c) The author.

28 Pendragon Castle, Mallerstang, near Kirkby Stephen, Cumbria. () The author.

29 The Maen Huail, Ruthin, Wales. (C) The author.

30 An explanatory plaque, Maen Huail, Ruthin, Wales. (๑ The author.

31 Illuminated medallion 49 from the fifteenth-century Histoire Universelle. ( $)$ The University of Manchester.

32 Tintagel viewed from across the causeway with the haven in the foreground. (c) The author.

\section{Maps}

1 The Roman Empire in the second half of the second century CE. $\quad 16$

2 The 'Sarmatian connection'. 43

3 Roman Britain. $\quad 55$

4 Ancient Greece. 122

5 Britain after Rome. 164

6 Britain and Ireland. 227

7 Localising Arthur. 265 